\title{
G Antigen 5
}

National Cancer Institute

\section{Source}

National Cancer Institute. G Antigen 5. NCI Thesaurus. Code C104482.

G antigen 5 (117 aa, $\sim 13 \mathrm{kDa}$ ) is encoded by the human GAGE5 gene. This protein may play a role in tumor formation. 